\title{
Conjunctival Melanoma pT3d TNM Finding v8
}

National Cancer Institute

\section{Source}

National Cancer Institute. Conjunctival Melanoma pT3d TNM Finding v8. NCI Thesaurus.

Code C140597.

Conjunctival melanoma with tumor of any size invading the nasolacrimal duct and/or lacrimal sac and/or paranasal sinuses. (from AJCC 8th Ed.) 